ROCZNIKI TEOLOGICZNE

Tom LXVIII, zeszyt $1-2021$

DOI: https://doi.org/10.18290/rt21681-3

KS. MICHAL HOSPODÁR

\title{
ZASTOSOWANIE LOGOTERAPII W POSŁUDZE KAZNODZIEJSKIEJ
}

\author{
THE APPLICATION OF LOGOTHERAPY IN THE PREACHING
}

\begin{abstract}
A b s t r a c t. Even today, in a society strongly marked by secularism and globalization, the Church is sent to proclaim the faith in Jesus Christ and his saving act. The resurrected Jesus himself entrusted this task to the Church before his ascension: "So go, teach all nations and baptize them" (Mt 28, 19). The proclamation of the Gospel is at the beginning of all the apostolic activity of the Church. She can never give up this eminent role because she would cease to be the authentic Church of Christ. The proclamation involves two levels: content and formal. In this paper, we will focus on the content level, specifically the existential issues of human existence. We start from the assumption of a general human desire for meaning. The search for meaning in psychology and psychotherapy was developed by Viktor E. Frankl (1905-1997), when after a horrible personal experience from the Auschwitz concentration camp, he developed his own therapeutic method, the so-called logotherapy. In the following text we will focus on the application of some principles of logotherapy in practical preaching activities. The topic is also relevant in connection with the global pandemic, which unexpectedly and dramatically "forced" humanity to abandon its existing certainties and look for new ones.
\end{abstract}

Key words: logotherapy; homily; Logos; Christ; meaning.

Jednym z decydujących obszarów duszpasterskich dla umacniania wiary religijnej i formacji życia moralnego chrześcijan jest głoszenie słowa Bożego. W dzisiejszych ponowoczesnych czasach kaznodzieja i jego posługa napotykają we wspólnocie kościelnej na szczególnie wysokie wymagania. Tym bardziej obecnie, gdy osobisty kontakt księdza z ludźmi w związku z obecnym kryzysem spowodowanym przez koronawirusa jest mocno ograniczony. Warto podkreślić, że w szczytowym okresie pandemii wierzący byli uzależnieni wyłącznie

Ks. dr MichAL HoSPODÁR - Gréckokatolícka teologická fakulta Prešovskej Univerzity v Prešove; adres do korespondencji: Slovakia PU GTF Prešov, Słowacja; e-mail: michal.hospodar@unipo.sk; ORCID: https://orcid.org/0000-0002-0934-266X. 
od oglądania nabożeństw za pośrednictwem mediów audiowizualnych. Kryzys wstrząsnął istotami życia, zwłaszcza wśród ludzi niestabilnych religijnie i poszukujących. Skłonił ponadto do poszukiwania odpowiedzi na poważne pytania egzystencjalne związane z życiem osobistym. W podobnym duchu doświadczenie pandemii ocenił Ojciec Święty Franciszek: „Ta dramatyczna sytuacja uwidoczniła naszą bezbronność i potrzebę zbawienia, zakwestionowała wiele pewników, na których opieraliśmy codzienność, zrodziła podstawowe pytania o szczęście i o to, co w życiu najważniejsze. Koronawirus przypomniał nam o sprawach najważniejszych, o tym, co zaniedbaliśmy w życiu, podczas gdy skupialiśmy się na ułudach szczęścia". Innymi słowy, w czasach kryzysu nie ma miejsca na powierzchowność, ale odwrotnie - jest wymaganie, by wypłynąć na głębię. Do pogłębiania wiary wzywał Kościół już papież Jan Paweł II, gdy na przełomie tysiąclecia sformułował swoje bezwzględne wezwanie Duc in altum! (Novo millenio ineunte, $\mathrm{nr} 38$ ).

\section{POWODY GŁOSZENIA - LOGOS}

„Przeto wiara rodzi się z tego, co się słyszy, tym zaś, co się słyszy, jest

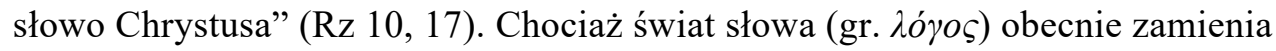

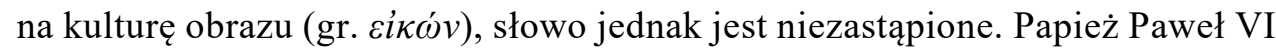
$(†$ 1978) podsumował to w swojej słynnej adhortacji poświęconej ewangelizacji. Wypowiedział się tam następująco:

Znamy też zdania wielu psychologów i socjologów, którzy utrzymują, że cywilizacja słowa, jako nieskuteczna i nieużyteczna, już się przeżyła, a obecnie następuje nowy styl życia, cywilizacja obrazu. Taki stan rzeczy łatwo podsuwa myśl, że do głoszenia Ewangelii trzeba stosować takie świeże środki, jakimi dysponuje ta cywilizacja. Zresztą, w tym kierunku już podjęto dobre i udane eksperymenty. Możemy je tylko pochwalić i zachęcić, aby te usiłowania coraz intensywniej prowadzić dalej. A niechęć, wywołana dziś nadmiarem pustych mów, i aktualność całkiem innych form przekazu społecznego nie powinna osłabiać mocy słów, ani odebrać im zaufania. Słowo zawsze posiada swą wyższość i skuteczność, zwłaszcza gdy niesie z sobą moc Bożą. Z tego powodu i w naszych czasach zachowuje swą aktualność Pawłowe: „wiara ze słuchania”. Prawidłowość wskazuje tutaj na to, że usłyszane słowo prowadzi do wierzenia (Evangelii nuntiandi, 42).

Człowiek odpowiada na głoszenie Ewangelii, otwierając się lub nie na przyjęcie Chrystusa $-\Lambda^{\prime} \mathrm{O} Г О \Sigma$, czyli najbardziej istotnej prawdy o Bogu, o sobie

\footnotetext{
${ }^{1}$ FrAntišEK, Úvod pápeža Františka ku knihe Spoločenstvo a nádej. Dosvedčovat' vieru v čase koronavírusu, https://www.tkkbs.sk/view.php?cisloclanku=20200728029 (dostęp: 30.07.20 20).
} 
samym oraz o zbawieniu. Te trzy poziomy są ze sobą ściśle powiązane, ponieważ dają człowiekowi odpowiedź na podstawowe pytania egzystencjalne: kim jestem? skąd pochodzę? oraz dokąd zmierzam? W rzetelnym podejściu do odpowiedzi na te pytania (motywowane religijnie lub świecko) odnajdujemy podstawowy sens życia ludzkiego. W przeciwnym razie osoba, która nie zada tych pytań, może zostać skazana na cierpienie z powodu utraty sensu swojego życia.

\section{FORMY GLOSZENIA}

Kerygma (gr. Kí $\gamma_{\gamma \mu \alpha}$ - głoszenie) jest podstawową lub pierwszą (misyjną) formą głoszenia Ewangelii. Typowe tematy kerygmy znajdujemy w pismach Nowego Testamentu. Najstarszym znanym kerygmatem jest katecheza Apostoła Piotra w Pięćdziesiątnicę (Zesłanie Ducha Świętego) wygłoszona do żydowskiego audytorium (por. Dz 2, 14-36). Wywarła ona tak wielki wpływ, że około trzech tysięcy osób od razu przyjęło chrzest. Inne mowy można znaleźć w listach apostoła Pawła. Przykładem może być tutaj jego przemówienie w Antiochii Pizydyjskiej, także adresowane do Żydów (por. Dz 13, 26-41). $\mathrm{Na}$ uwagę zasługuje ponadto wyjątkowe wystąpienie Apostoła Narodów na ateńskim wzgórzu przed zgromadzonymi poganami (por. Dz 17, 22-31). „Kerygmat jest więc istotą Ewangelii i podstawowym źródłem wczesnochrześcijańskiej tradycji [...]"2.

Kerygma to przede wszystkim żywe słowo o Bogu. Istotą kerygmatu jest prawda, że Jezus Chrystus umarł i zmartwychwstał, by darować człowiekowi życie wieczne. Jest z nim ponadto związane wezwanie do pokuty i przyjęcia darów Ducha Świętego, a tym samym zbawienia. Kerygma to przesłanie, które sam Bóg pozostawił nam w Piśmie Świętym. Głosić kerygmat może ten, kto jest upoważniony przez Kościół, a jego głoszenie jest aktualizowane dla tego, kto go przyjmuje. Bóg nie tylko przemawia, lecz także działa w swoim słowie („słowo Boże jest żywe i skuteczne” Hbr 4, 12) ${ }^{3}$.

Kapłan, teolog i kaznodzieja pełnią tę samą służbę w relacji do słowa Bożego. Głoszą oni łaskę Boga, który pozwala słuchać Jego Słowo. Głoszenie staje się zbawieniem tego, kto je przyjmuje. Kerygma uobecnia Chrystusa -

\footnotetext{
2 J. HeriBAn, Príručnýlexikón biblických vied, Slovenský ústav sv. Cyrila a Metoda, Rím 1992, s. 577.

${ }^{3}$ Por. M. Hospodár, Pastorálna teológia. Vybrané kapitoly, GTF PU, Prešov 2010, s. 46; M. KARDIS, Prvokrest'anská tradícia I [elektronický zdroj], GTF PU v Prešove, Prešov 2012, s. 56-57.
} 
Logos we wspólnocie i sama kształtuje wspólnotę w celu ustanowienia wspólnoty chrześcijańskiej poprzez nawrócenie i chrzest. Wyraża istotę i podstawę zbawienia, perspektywy rozwiązań, które wskazują na prawdy chrześcijańskie oraz racjonalność wiary. Ewangelizacja przedstawia słowo Boże jako potężne, które przynosi zbawienie, wzbudza wiarę, ponadto jest związane z osobistą akceptacją głoszącego.

Warto także zwrócić uwagę na adresata. Otóż kerygma jest skierowana do niewierzących, niepraktykujących ochrzczonych, poszukujących, jak i wierzących in statu fieri. Przepowiadanie bez kerygmatu skazuje nas, kapłanów, na niepowodzenie. Jeśli kerygmat osiągnął swój cel, jego konsekwencją jest głoszenie wspólnotowe we wspólnocie kościelnej. To zagadnienie zostanie rozwinięte w kolejnej części opracowania.

\section{TREŚĆ GŁOSZENIA I SZUKANIE SENSU}

Sobór Watykański II (1962-1965) przypomina: „By zaś przepowiadanie kapłańskie, w tak trudnych często okolicznościach dzisiejszego świata, właściwiej poruszyło umysły słuchaczy, winno ono wyjaśnić Słowo Boże nie w sposób tylko ogólny i abstrakcyjny, lecz dostosować odwieczną prawdę Ewangelii do konkretnych warunków życia" (Presbyterorum ordinis, nr 4). Dlatego kapłan powinien żyć pośród powierzonej mu wspólnoty, aby lepiej poznać jej mentalność i kulturę oraz przedstawić jej słowo Boże w zrozumiałym stylu i języku. Powinien odpowiadać na pytania zadawane przez słuchaczy także wirtualnie. W tym sensie formułujemy podstawowe treści przepowiadania kapłańskiego:

1) Chrystus żywy i zmartwychwstały;

2) perykopę z listów apostolskich lub Ewangelii (jedną myśl);

3) sytuacje egzystencjalne (choroba, śmierć, małżeństwo, kryzys życiowy);

4) przemówienia okolicznościowe (pierwsza Komunia św., początek roku szkolnego, różne rocznice).

Zwróćmy teraz uwagę na sytuacje egzystencjalne w życiu każdego człowieka. Stanowią one jeden ze składników treści orędzia religijnego, gdyż treść przepowiadania nie może być oderwana od życia ${ }^{4}$. $Z$ jednej strony w słowie Bożym często spotykamy egzystencjalne prawdy o szczęściu, sensie życia, miłości,

\footnotetext{
${ }^{4}$ Jak wynika z badań, pytania o sens życia dotykają głównie ludzi młodych, którzy są u progu budowania własnej osobowości. Dotyczą ponadto ludzi w końcowym okresie życia.
} 
cierpieniu i śmierci. Jednak ich zrozumienie, zaakceptowanie i rozwiązania w świetle Pisma Świętego nie jest możliwe bez nadprzyrodzonego poziomu wiary. Z drugiej strony w koncepcji psychiatry i psychoterapeuty Viktora Frankla, stosując tzw. logoterapię treści (także w przepowiadaniu słowa), wiążemy ją treściowo z życiem odbiorców. Polegamy jednocześnie na ludzkiej zdolności do przekształcania wszelkich (nawet negatywnych) aspektów życia w pozytywną i konstruktywną rzeczywistość. Znajdziemy tu podstawową triadę: cierpienie, wina i śmierć.

Cierpienie jest częścią każdego życia, towarzyszącą człowiekowi od urodzenia aż do śmierci. Cierpienia nie znosimy tylko w chorobie i bolesnych stanach spowodowanych nagłym wypadkiem. Cierpienie przeżywa dziecko, gdy nie ma wystarczających relacji emocjonalnych z rodzicami, gdy dorośli nie są zainteresowani potrzebami dzieci lub gdy dziecko znajdzie się w sytuacji rozwodu swoich rodziców, którzy rozwiązują swoje spory za pośrednictwem dziecka. Cierpienie przeżywa również małżonka alkoholika lub mąż z histeryczną partnerką. Podobnie dzieje się w sytuacji osób starszych pozostawionych bez pomocy, a nawet żyjących w kręgu rodzinnym, w którym są jednak ignorowane przez własne dzieci lub wnuki. Znamy też inne formy, takie jak „cierpienie z przyczyn społecznych”, gdy człowiek znajduje się na marginesie społeczeństwa, dotknięty jest ubóstwem społecznym, bezrobociem, przeżywa rozstanie z bliskimi, niezrozumienie lub rozczarowanie itd. ${ }^{5}$

Drugą z form przywołanej triady jest tzw. poczucie winy. Jako stan może być ono rozumiane w wymiarze okazji do wprowadzenia zmian na lepsze. Staje się zatem sposobnością do intensywnego rozwoju człowieka.

Trzecim zakresem triady jest kryterium śmierci. Jest ona częścią każdego życia ludzkiego, jest rzeczywistością, którą świadomie lub nieświadomie odpycha się, a czasem wręcz zaprzecza jej istnieniu. Strach przed śmiercią przeżywa się nie tylko w momencie zbliżania się do końca życia, ale ten sam lęk przenika człowieka w stosunku do bliskich w ostatnich chwilach ich życia.

Przedstawiona triada znajduje przełożenie w pracach Viktora Emila Fran$\mathrm{kla}^{6}$. Jest on znany z tego, że w swojej koncepcji nie uległ charakterystycznemu dla czasów własnej twórczości psychologicznemu redukcjonizmowi.

\footnotetext{
${ }^{5}$ Por. J. STEMPELOVÁ, Praktické využitie myšlienok Viktora E. Frankla v pastorálnej psychológii, w: Hladanie zmyslu života ako pastoračná výzva, red. M. Hospodár, GTF, Prešov 2016, s. 48.

${ }^{6}$ Viktor E. Frankl urodził się 26 marca 1905 r. w Wiedniu. Po studiach medycznych pracował jako psychiatra w stolicy Austrii, aż do wybuchu II wojny światowej. Jako żyd został deportowany do hitlerowskich obozów koncentracyjnych, gdzie często stawał w obliczu ludzkiego cierpienia i śmierci. Po wyzwoleniu wrócił do rodzinnego miasta, gdzie poza praktyką lekarską opracował
} 
Uznał natomiast duchowy wymiar ludzkiego życia. W swojej egzystencjalnej analizie człowieka religijnego Frankl widzi przestrzeń dla fenomenologicznego dowodu na istnienie Boga. „Doświadczenie religii w relacji Ja-Ty jest istotną cechą religijności. Jeśli chodzi o pogląd ludzi, że są wierzącymi, ale konfesyjnie nie złączeni, Frankl zwraca uwagę, że w poszukiwaniu prawdy człowiek stosuje głównie język macierzyński, a język religijny jest związany z tradycją wyznaniową" ${ }^{7}$. Według Frankla sumienie odgrywa ogromną rolę w logoterapii. Sumienie definiuje on jako zdolność wyczucia niepowtarzalnego i wyjątkowego sensu ukrytego w każdej sytuacji. Jest to głos transcendencji, którego nawet osoba niereligijna doświadcza jako instancji, przed którą należy udzielić odpowiedzi. Frankl wprowadza również pojęcie „nieświadomości duchowej”, w której umieszcza sumienie. Wskazuje też, że religijność objawia się w snach w postaci symboli. Ma to związek z nieświadomą religijnością, która gdy jest stłumiona, może mieć patologiczne konsekwencje. Frankl dostrzeg1 ważną psychoterapeutyczną i profilaktyczną rolę religii w życiu człowieka. Według niego stosunek do Absolutu daje poczucie bezpieczeństwa. W odniesieniu do religijności Frankl stwierdza ponadto, że poczucie sensu można również doświadczyć poprzez osobiste zawierzenie.

\section{POSZUKIWANIE SENSU W NAUCE}

Kościół - świadomy swojej misji - nie dystansuje się od poważnych, uniwersalnych pytań i problemów. W obecnych burzliwych czasach, pełnych technicznych odkryć, ale i zaskakujących zwrotów akcji, wskazuje na prawdziwe wartości życia gwarantujące stabilność. Fragmentaryzacja nauki z jednej strony doprowadziła ludzkość do wielkich odkryć naukowych i technicznych, do rozwoju gospodarki i przemysłu, jednak z drugiej strony rozwój ten może stanowić zagrożenie dla ludzkości. Jan Paweł II w swoim nauczaniu akcentuje: „Odkrycia naukowe i techniczne prowadzą bowiem z jednej strony do ogromnego rozwoju gospodarki i przemysłu, z drugiej jednak stwarzają

także międzynarodowe wykłady i publikacje. Założył tzw. trzecią wiedeńską szkołę psychologiczną. Zmarł w 1997 r., został pochowany na Cmentarzu Centralnym w Wiedniu. Na Słowacji jego spuściznę rozwija Słowacki Instytut Logoterapii.

${ }^{7}$ M. STRížENEC, Novšie psychologické poznatky na religiozitu a spiritualitu, s. 10-11, http:// www.psychologia.sav.sk/upload/MS_Novsie-psychologicke-pohlady-na-religiozitu-a-spiritualitu.pdf (dostęp: 30. 07.2020). 
nieuniknioną konieczność jednoczesnego poszukiwania sensu, które ma zagwarantować, że nowe odkrycia będą służyć prawdziwemu dobru jednostek oraz społeczeństwa ludzkiego jako całości” (Ex corde Ecclesiae, nr 7). Poszukiwanie takie powinno również uwzględniać, iż ,jego chrześcijańska inspiracja pozwala mu uwzględniać w badaniach naukowych także wymiar moralny, duchowy i religijny oraz oceniać zdobycze nauki i techniki z punktu widzenia integralnego dobra osoby ludzkiej" (Ex corde Ecclesiae, $\mathrm{nr} 7$ ). W istocie jest to rodzaj organicznej syntezy, dążenie do integracji nauki, „nieustanny wysiłek określania właściwego miejsca i znaczenia każdej z poszczególnych dyscyplin w ramach ogólnej wizji osoby ludzkiej i świata, w świetle Ewangelii, a zatem wiary w Chrystusa-Logos jako centrum stworzenia i ludzkich dziejów" (Ex corde Ecclesiae, nr 16).

Zarysowane powyżej poszukiwanie sensu i umiejscowienie własnej specjalizacji w szerszej wizji nie jest łatwe w obecnym stanie wiedzy oraz podziale poszczególnych dyscyplin naukowych, a także w ograniczaniu się do bardzo wąskiej specjalizacji. Ponadto sama nauka nie może udzielić pełnej odpowiedzi na pytanie o sens, chociaż jest to istotny problem dla kultywowania nauki.

Kardynał Zenon Grocholewski w czasie uroczystości nadania mu doktoratu honoris causa Uniwersytetu Komeńskiego w Bratysławie 12 września 2002 r. powiedział:

Teologia odgrywa szczególnie ważną rolę w poszukiwaniu syntezy wiedzy, wnosi również wkład do wszystkich innych dyscyplin w poszukiwaniu ich sensu, ponieważ nie tylko pomaga im określić, w jaki sposób ich odkrycia wpłyną na życie ludzi i społeczeństw, ale także wskazuje perspektywę i kierunek, których nie ma w ich metodologiach ${ }^{8}$.

W tej perspektywie można zauważyć, że prawdziwemu poznaniu naukowemu z konieczności towarzyszy cnota mądrości, bez której sama wiedza traci swoją integralność. Konstytucja apostolska Sapientia christiana, odwołując się do soborowego stwierdzenia (Gaudium et spes, nr 43 n.), rozpoczyna się sformułowaniem: „Mądrość chrześcijańska, której z boskiego polecenia Kościół naucza, pobudza ustawicznie wiernych do pilnego ujmowania w jednej żywotnej syntezie spraw i przedsięwzięć ludzkich wraz z dobrami religijnymi, pod których kierunkiem wszystkie one wzajemnie się zespalają w jedną całość na chwałę Bożą oraz ku pełnej doskonałości człowieka, odejmującej zarówno dobra cielesne, jak i duchowe" (nr 1).

\footnotetext{
${ }^{8}$ Prednáška po prevzatí čestného doktorátu UK, „Naša univerzita” 59(2002), nr 2, s. 8.
} 


\section{RÓŻNICE MIĘDZY HOMILIĄ A TERAPIĄ}

Wróćmy do tematu artykułu i przyjrzyjmy się spójnościom i różnicom między przepowiadaniem kościelnym a logoterapią. Pierwszą i najbardziej istotną percepcją jest ludzkie słowo, którym posługuje się zarówno homileta, jak i psychoterapeuta. Jednak homilia wygłaszana w środowisku sakralnym nie jest ani psychoanalizą, ani psychoterapią, oddziałuje na innym poziomie. Chociaż zarówno logoterapeuta, jak i kaznodzieja mają przed sobą osobę, która ma problemy, dla logoterapeuty jest to raczej pacjent lub klient, podczas gdy kaznodzieja ma przed sobą grzesznika, do którego został wysłany, by głosić ukrzyżowanego i zmartwychwstałego Jezusa Chrystusa.

Logoterapeuta szuka punktów odniesienia w naturalnej motywacji, podczas gdy kaznodzieja ma do dyspozycji również motywy nadprzyrodzone. Logoterapeuta polega na sile słowa ludzkiego, kaznodzieja - na mocy słowa Bożego. I tu jest podstawowa różnica między jakąkolwiek jakościową logoterapią a homilią ${ }^{9}$.

Zarówno logoterapia, jak i homilia nadają życiu sens, prowadzą do niego, nie pozostawiają człowieka na łasce przeznaczenia, ale podnoszą go, ukazują światło w sytuacji bez wyjścia. Tworzą ponadto punkty wsparcia, dzięki którym można uchwycić powody, dla których warto żyć i nie rezygnować, a nawet odkrywać na nowo radość z życia. W życiu człowieka nie chodzi bowiem o nadawanie mu sensu, ale o jego poszukiwanie. Frankl twierdzi, że człowiek, szukając i odkrywając wartości, może formułować sens życia. Jest to panaceum na obserwowane w pandemii tendencje, gdzie można $\mathrm{z}$ łatwością zaobserwować powszechną dezintegrację potrzeb duchowych oraz utratę sensu ${ }^{10}$.

W powyższym wymiarze warto spojrzeć na samą homilię. Dochodzi w niej bowiem do interesującego zjawiska, jakim jest określanie celu ludzkiego życia. Czytamy to wyraźnie, w Liście do Hebrajczyków: „I my zatem, mając dokoła siebie takie mnóstwo świadków, odłożywszy wszelki ciężar, [a przede wszystkim] grzech, który nas łatwo zwodzi, winniśmy wytrwale biec w wyznaczonych nam zawodach. Patrzmy na Jezusa, który nam w wierze przewodzi i ją wydoskonala. On to zamiast radości, którą Mu obiecywano, przecierpiał krzyż, nie bacząc na [jego] hańbę, i zasiadł po prawicy tronu Boga" (Hbr 12, 1-2). Oczywiście nadprzyrodzona motywacja do osiągnięcia tego wynika z uprzednio postawionego celu.

${ }^{9}$ L. Petrík, Homília ako špecifická forma logoterapie a ponuky zmyslu života, w: Hladanie zmyslu života ako pastoračná výzva, red. M. Hospodár, GTF PU, Prešov 2016, s. 70-71.

${ }^{10}$ Por. S. Hvozdík, Celistvý obraz o človeku a logoterapia, „Radost' a nádej” 21 (2018), č. 1-2, s. 25. 
W tym kontekście warto zauważyć, że przygotowując homilię, kaznodzieja opiera się przede wszystkim na tekstach Pisma Świętego. Powinien jednak wiedzieć, że dziś Pismo Święte nie jest już dla słuchacza naturalną prawdą, którą on automatycznie przyjmuje. $Z$ tego powodu, najsilniejszym argumentem, by przekonać słuchacza o Bożej prawdzie i miłości, jest osobiste doświadczenie wiary. Nie ma przeciwko temu silniejszych argumentów. „Skosztujcie i zobaczcie, jak dobry jest Pan, szczęśliwy człowiek, który się do Niego ucieka" (Ps 34, 9). To wyzwanie dotyczy każdego człowieka na jego drodze w poszukiwaniu Boga. Akcentowanie osobistego doświadczenia ma swoje miejsce również $\mathrm{w}$ dialogu terapeutycznym w logoterapii ${ }^{11}$, co ukazuje zbieżność poziomu pracy psychologa oraz kaznodziei.

\section{WPŁYW SEKULARYZACJI NA SŁUŻBĘ KAZNODZIEJSKĄ}

Pierwszą rzeczą, która odzwierciedla się w homilii, jest osobista wiara kaznodziei. Kolejnym elementem jest entuzjazm dla sprawy Bożej. Tylko gorliwy ksiądz może zapalić innych. Entuzjazm nie jest przejawem zewnętrznego teatralnego przemawiania kaznodziei, który może „deptać” słuchaczy, ale współpraca z Duchem Świętym i jego tajemniczym wpływem na duszę. Przez analogię można powiedzieć, że dla wzrostu nasion jest lepszy łagodny deszczyk niż częste grzmoty i błyskawice. Niekontrolowana burza słów w homilii jest często oznaką braku przygotowania do głoszenia. Kapłan-kaznodzieja także jest narażony na niebezpieczeństwo postępującej sekularyzacji. Sekularyzmu, który podstępnie stara się dotknąć wszystkie elementy życia i działalności kapłańskiej, nie można przezwyciężyć bez zdrowej duchowości. Dobra homilia jest owocem życia duchowego (medytacji i modlitwy), znajomości Pisma Świętego (egzegezy) i osobistego świadectwa. Tylko ten, kto ma osobiste doświadczenie z Chrystusem, może to przekazać innym. Podobnie jak apostoł Piotr, który zaparł się Jezusa, ale także poczuł Jego przebaczenie. Dotyczy to także apostoła Pawła, który stał się prześladowcą chrześcijan, a następnie został największym w historii głosicielem Chrystusa.

Przyjmując powyższe stwierdzenia warto zauważyć, że duchowa pustka i zagrożenie sekularyzmem „krzyczą” z homilii, które nie zostały uświęcone modlitwą i medytacją. Soborowy dekret o działalności i życiu kapłańskim

${ }^{11}$ Jednym z czynników wpływających na sukces logoterapii Frankla w skali światowej jest to, że miał on doświadczenie więźnia obozów koncentracyjnych, co znacząco wpłynęło na jego koncepcję człowieka, której centralnym pojęciem jest kategoria sensu życia. 
stwierdza: „Szukając bowiem odpowiedniejszego sposobu przekazywania innym rzeczy, które były przedmiotem ich kontemplacji, będą głębiej odczuwać «niedościgłe bogactwo Chrystusa» (Ef 3,8) i wieloraką mądrość Bożą" (Presbyterorum ordinis, nr 13).

Celem artykułu było określenie wspólnych powiązań między kościelną kaznodziejską posługą oraz służbą psychologiczno-terapeutyczną. Jak można zaobserwować, słowo Boże, które w homilii jest poddane prawidłowościom posługiwania się słowem ludzkim, ma niezastąpioną wartość w wypełnianiu swojej misji terapeutycznej. Sprzyja to temu, by obie te posługi mogły wpływać na siebie i wzajemnie się uzupełniać. Wiąże się to z czynnikiem osobistym, który jest ważny zarówno dla działań psychoterapeutycznych, jak i w przekazywaniu samego orędzia Ewangelii. Reasumując warto zauważyć, że zaprezentowane $\mathrm{w}$ treści opracowania koncepcje mają swoich kontynuatorów. Warto zwrócić uwagę na dorobek profesora Kazimierza Popielskiego, który w swoich pracach podejmuje i rozwija wskazane tutaj konteksty.

\section{BIBLIOGRAFIA}

Dokumenty Soboru Vatykańskiego, Spolok sv. Vojtecha, Trnava 2008.

FRANTIŠEK, Úvod pápeža Františka ku knihe Spoločenstvo a nádej. Dosvedčovat' vieru $\mathrm{v}$ čase koronavírusu, https://www.tkkbs.sk/view.php?cisloclanku=20200728029 (dostęp: 30.07.2020).

GrocholewsKi Z., Prednáška po prevzatí čestného doktorátu UK, „Naša univerzita” 59(2002) nr 2, s. 5-9.

Heriban J., Príručný lexikón biblických vied, Slovenský ústav sv. Cyrila a Metoda, Rím 1992.

Hladanie zmyslu života ako pastoračná výzva, red, M. Hospodár, GTF PU, Prešov 2016.

HosPodÁR M., Pastorálna teológia. Vybrané kapitoly, GTF PU, Prešov 2010.

Hvozdík, S., Celistvý obraz o človeku a logoterapia, „Radost' a nádej” 21 (2018), nr 1-2, s. 17-30.

JÁn PAVOL II, „Ex corde Ecclesiae”. Apoštolská konštitúcia o katolíckych univerzitách, Spolok sv. Vojtecha, Trnava 1998, https://www.kbs.sk/obsah/sekcia/h/dokumenty-a-vyhlasenia/p/ dokumenty-papezov/c/ex-corde-ecclesiae (dostęp: 30.07.20 20).

JÁn PAVOL II, „Novo millenio ineunte”. Apoštolský list na začiatku nového tisícročia, SSV, Trnava 2001.

JÁN PAVOL II, „Sapientia christiana”. Apoštolská konštitúcia o štúdiu na cirkevných univerzitách a fakultách, Spolok sv. Vojtecha, Trnava 1999.

KARDIS M., Prvokrest’anská tradícia I [elektronický zdroj], GTF PU v Prešove, Prešov 2012. 
PAVOL VI, „Evangelii nuntiandi”. Apoštolská exhortácia o ohlasovaní evanjelia v dnešnom svete, SSV, Trnava 1999.

PETRík L', Homília ako špecifická forma logoterapie a ponuky zmyslu života, w: Hladanie zmyslu života ako pastoračná výzva, red. M. Hospodár, GTF PU, Prešov 2016, s. 67-76.

Stempelová J., Praktické využitie myšlienok Viktora E. Frankla v pastorálnej psychológii, w: Hl'adanie zmyslu života ako pastoračná výzva, red. M. Hospodár, GTF PU, Prešov 2016.

STRÍŽENEC M., Novšie psychologické poznatky na religiozitu a spiritualitu, www.psychologia.sav.sk/ upload/MS_Novsie-psychologicke-pohlady-na-religiozitu-a-spiritualitu.pdf (dostęp: 30.07.2020).

\section{ZASTOSOWANIE LOGOTERAPII W POSŁUDZE KAZNODZIEJSKIEJ}

\section{Streszczenie}

Nawet dzisiaj, w społeczeństwie silnie naznaczonym sekularyzmem i globalizacją, Kościół jest posłany, aby głosić wiarę w Jezusa Chrystusa i Jego zbawczy akt. Sam zmartwychwstały Jezus powierzył to zadanie Kościołowi przed swoim wniebowstąpieniem: „Idźcie więc i nauczajcie wszystkie narody, udzielając im chrztu" (Mt 28, 19). Głoszenie Ewangelii jest początkiem całej apostolskiej działalności Kościoła. Nigdy nie może zrezygnować z tej wybitnej roli, ponieważ przestałaby być autentycznym Kościołem Chrystusa. Proklamacja obejmuje dwa poziomy: merytoryczny i formalny. W tym artykule uwaga zostanie skoncentrowana na poziomie merytorycznym, a konkretnie na zagadnieniach bytowych ludzkiej egzystencji. W tekście myśl rozpoczyna ogólne założenie dotyczące ludzkiego pragnienia sensu. Poszukiwanie sensu w psychologii i psychoterapii rozwinął Viktor E. Frankl (1905-1997), gdy po dramatycznych osobistych przeżyciach związanych z pobytem w obozach koncentracyjnych opracował własną metodę terapeutyczną - logoterapię. W artykule skupiamy się na zastosowaniu niektórych zasad logoterapii w praktycznych działaniach kaznodziejskich. Temat jest również istotny $\mathrm{w}$ związku $\mathrm{z}$ globalną pandemią, która nieoczekiwanie „zmusiła” ludzkość do porzucenia dotychczasowych pewników i poszukiwania nowych elementów stabilizacji bytowej.

Słowa kluczowe: logoterapia; homilia; Logos; Chrystus; znaczenie. 